\title{
PORTUGAL E O ESTADO PROVIDÊNCIA: FRAGILIDADES, DEPENDÊNCIAS E AMEAÇAS'
}

\author{
Portugal and the Welfare State: fragilities, dependencies and threats
}

Elísio Estanque ${ }^{2}$

\begin{abstract}
Resumo
0 presente texto recupera algumas discussões em torno do Estado na sua relação com a sociedade. Pretende-se questionar o potencial e os limites das políticas públicas no atual contexto de austeridade, indo ao encontro da ação redistributiva das instituições e procurando analisar o significado dos sistemas sociais no imaginário dos cidadãos (sobretudo em áreas como a saúde, a educação e a previdência). Tendo presente a recente tendência de intensificação das desigualdades estruturais quer na escala da Europa quer no seio dos países membros, admite-se a titulo de hipótese que a solidez do sistema e a coesão social nos países da UE possam colapsar ou a ser fortemente constrangidos na sua ação reguladora. Em sociedades como a portuguesa, de forte tradição católica, com culturas paroquiais muito intensas e que passaram por ditaduras-militares duradouras, as novas classes médias (assalariadas) foram estruturadas muito tardiamente. No caso português, foi sobretudo no período democrático que tal processo teve lugar, daí resultando que os segmentos sociais da classe média (assalariada e mesmo empresarial) que se regem pelos princípios meritocráticos sejam praticamente residuais. É este o quadro em que se inscrevem as razões da fragilidade do Estado providência e as dificuldades que hoje enfrenta no contexto europeu e português.
\end{abstract}

Palavras-chave: Portugal; Estado Providência, Austeridade.

\begin{abstract}
This article recovers some discussions about the State in its relationship with society. The aim is to question the potential and limits of public policies in the current context of austerity, in order to meet the redistributive action of institutions and to analyse the meaning of social systems in the citizens' imagination (especially in areas such as health, education and welfare). Bearing in mind the recent trend towards intensifying structural inequalities both within Europe Union as well as within its Member States, it is argued that the strength of the system and the social cohesion in EU countries may collapse or be strongly constrained in its regulatory action. In societies such as Portugal, with a strong Catholic tradition, with very intense parish cultures, which have undergone lasting military dictatorships, the new middle classes (waged) were structured very late. In the Portuguese case, it was mainly in the democratic period that this

\footnotetext{
1 O presente texto é uma versão adaptada para o público brasileiro da fusão de artigos publicados em: Silva, Filipe Carreira (org.) (2012), Os Portugueses e o Estado Providência. Lisboa: ICS; e "O Estado Social de Reflexão e Crítica, n 73, pp. 39-80, 2012.

2 Professor do Centro de Estudos Sociais da Universidade de Coimbra. E-mail: elisio.estanque@gmail.com.
} em Causa: instituições sociais, politicas sociais e movimentos sociolaborais”, Revista Finisterra - Revista
\end{abstract}


Portugal e o Estado Providência | Elísio Estanque

process took place, resulting in a situation in which the middle-class (wage-earning and even entrepreneurial) social segments that are governed by meritocratic principles are practically residual. This is the framework for the reasons of the fragility of the welfare state and the difficulties it faces today in the European and Portuguese context.

Keyword: Portugal; Welfare State, Austerity.

\section{Concepções e contradições do Estado moderno}

O Estado e o seu significado sociológico permanece intimamente ligado à história do Ocidente, onde, como é sabido, a Europa ocupa um lugar central. A génese do Estado remete para o poder, sendo que este reside, em última instância, na força, a começar pela força militar. Nessa medida, é nos exércitos, nos dotes de chefia dos seus líderes e na sua capacidade estratégica que repousa o domínio dos grandes impérios ou das cidades-Estado mais influentes da era clássica. Faz sentido remeter para essas fórmulas originárias do exercício do poder para refletirmos sobre o Estado e a sociedade. Todavia, até hoje o conceito de "Estado" permanece discutível quanto à sua origem e ao seu significado. O termo foi usado pela primeira vez por Maquiavel ( $O$ Príncipe, 1532), mas o nascimento do Estado moderno é posterior, sendo em geral situado no tratado de Paz de Westfália (1648), com o reconhecimento de governos soberanos sobre uma dada área territorial. Com uma Europa central devastada por guerras religiosas que duraram várias décadas, a paz foi muito dificilmente conseguida, ocorrendo num período de profunda viragem na correlação de forças entre as diversas potências europeias. O Estado-nação emerge das ruinas da cristandade medieval, resultado da desagregação dos grandes impérios: "A universalidade politica medieval, na sua unicidade e pouca diferenciação, sob a autoridade suprema do papa e do imperador, deu lugar a um sistema de Estados nacionais de variadas unidades políticas, soberanas e nacionais, que tinham de enfrentar e resolver o problema das relações com a Igreja, que permanecia universal e transnacional" (CRUZ, 1992, p. 829). A autoridade dos Estados traduziu-se, então, num consenso alargado em torno da soberania de cada território e das funções imputadas ao Estado, isto é: a) uma forma de governo dotada de instituições e meios para impor a sua 
Lei; b) um povo que aceita submeter-se a esse governo e com ele partilha determinados valores; e c) um território com fronteiras bem delimitadas.

$\mathrm{Na}$ famosa obra de Thomas Hobbes, Leviatã, o "estado de natureza" terá sido aquele em que, dadas as diferenças de poder e de inteligência entre os homens, e dado que os recursos são sempre escassos, a ausência de um poder dissuasor tende a suscitar uma guerra de todos contra todos. Ora, sendo a guerra permanente uma situação insustentável, é urgente contê-la ou prevenila. E é justamente pela necessidade de assegurar a paz que os homens tomam consciência da necessidade de promover um contrato, um compromisso, controlado por uma força centralizadora à qual a sociedade deve submeter-se. Embora, como este clássico reconheceu, o Estado seja em larga medida "uma ficção", ele transporta uma "vontade própria", mas que representa e incorpora a vontade colectiva dos cidadãos, criando e manuseando os mecanismos ativos que preservam os direitos e deveres de cada um.

Mas, à visão hobbesiana de uma autoridade centralizada imposta pelo Estado, outros pensadores, como John Locke, contrapõem uma ideia de soberania, igualmente representada pelo Estado, mas consentida pelos individuos, por cujas liberdades e direitos de propriedade aquele deve velar, caso contrário o poder de Estado perde legitimidade e os cidadãos têm o direito de revoltar-se. A perspetiva lockiana pressupõe um processo de consolidação de uma racionalidade aliada ao sentido de tolerância, respeito pelas liberdades, e à ideia de governo pelo consentimento, o que proporcionou e deu solidez ao conceito de contrato social como base fundamental de governação, de justiça e de progresso das sociedades. O estatismo de Hobbes e o liberalismo de Locke seriam ainda contrariados por um dos autores mais influentes do século das luzes: Jean-Jacques Rousseau.

Segundo Rousseau, a natureza e o ser humano induziram um direito natural que a sociedade perverteu. Antecipou a visão sociológica segundo a qual a origem das desigualdades entre os homens resulta da própria sociedade, da divisão do trabalho e da propriedade privada sem, no entanto, descurar o papel da racionalidade. Só através da razão pode ser criado um "pacto" capaz 
de permitir a passagem do estado natural ao estado "civil", passagem essa que teve consequências nefastas como a guerra e o egoísmo. Compete, portanto, ao Estado promover o contrato, apoiando-se na inteligência dos indivíduos, no seu pensamento racional-moral e promovendo leis que sejam expressão dessa vontade geral, a fim de suprir a tendência à desordem instigada pelo sistema social emergente. Porém, só o povo pode conferir legitimidade ao governo, que pressupõe o respeito pela liberdade, justiça e igualdade, os principais garantes do contrato social entre os súditos e os soberanos, cujas relações são de reciprocidade.

Embora, as reflexões filosóficas em torno do Estado remontem ao berço da civilização ocidental é, sobretudo, com a emergência do capitalismo moderno que se desenham as principais conceções a seu respeito, perante o triunfo da nova sociedade ocidental, e é a partir delas que importa entender - e se possivel reformular - a natureza complexa e contraditória do aparelho de Estado na sua relação com a economia e a sociedade em geral. Autores clássicos das ciências sociais como Max Weber e Émile Durkheim pensaram o papel do Estado moderno enquanto instância fundamental de racionalidade politica e de organização da ordem social e moral da sociedade. Já Karl Marx desenvolveu todo um edifício teórico em que o Estado capitalista é visto sobretudo, como aparelho de dominação associado à ordem econômica e ao poder do capital nas sociedades industriais. O que estes pensadores tiveram em comum e que nos pode ajudar a compreender os problemas atuais foi a sua perceção de que o Estado e a economia são dimensões inscritas na sociedade e na sua estrutura socioeconômica.

$\mathrm{Na}$ verdade, o mais importante é atentar na natureza contraditória, plural e complexa da sociedade moderna, cuja conflitualidade ganhou um carácter estrutural logo no seu processo de gestação. Desde finais do século XVIII que as guerras civis, os movimentos camponeses, a revolução burguesa e o movimento operário marcaram a Europa ocidental com sucessivas convulsões sociais e políticas, a provar como a consolidação das nações modernas esteve longe de ser um processo harmonioso. Daí que as preocupações com a lei, a ordem e a 
moral tivessem acompanhado as grandes correntes teóricas e filosóficas do pensamento social, muito embora, paradoxalmente, o triunfo da racionalidade ocidental tenha caminhado lado a lado com a instabilidade, o conflito e a luta entre classes.

É neste ponto que importa realçar a sagacidade de Marx ao antever a natureza eminentemente contraditória do capitalismo moderno e a sua propensão para aprofundar essas contradições, que até agora tem oscilado entre a tentação autodestrutiva e a capacidade regeneradora. Nesta perspetiva, o Estado, ainda que se imponha como uma instância superior e acima da sociedade, nunca se despe das relações de classe e, nesse sentido, assume-se como o principal veículo de legitimação e reprodução das fortes desigualdades sociais e econômicas por que se rege a sociedade capitalista. Do ponto de vista conceitual, as referências de Marx ao Estado são dispersas, pouco aprofundadas e por vezes contraditórias, estando mais presentes nos seus escritos históricos. Marx vê o Estado como uma dimensão do sistema de dominação de classes, considerando-o uma instituição "parasita" que serve os interesses da burguesia e dos altos funcionários, um "epifenómeno" das relações de propriedade, sobressaindo ainda no seu pensamento uma noção de "Estado instrumento" (cf. BOBBIO, 1979), noção esta que é particularmente realçada por Lenine $^{3}$. As análises marxistas mais elaboradas sobre a complexidade e as tensões internas que atravessam o Estado capitalista surgiram mais tarde (POULANTZAS, 1978; WRIGHT, 1978; EVENS et al., 1985; JESSOP, 1990).

As conceções e controvérsias acerca do Estado são tantas e tão diversas que não cabem nesta breve reflexão. Desde os defensores do laissez faire, do Estado mínimo, que apenas reconheciam o seu papel de "vigilante", garante da paz, dos direitos de propriedade e pouco mais, às teorias do estatismo mais abrangente, o Estado-sujeito ou o hobbesiano Leviatã, passando pela referida

\footnotetext{
3 Uma perspetiva que fica clara na sua obra O Estado e a Revolução: "Segundo Marx, o Estado é um órgão de dominação de classe, um órgão de opressão de uma classe por outra, é a criação da "ordem" que legaliza e consolida esta opressão, moderando o conflito de classes." (LENINE, 1978 [1917], p. 15).
} 
conceção leninista do Estado-instrumento, as premissas e conceitos em torno do Estado são difíceis de elencar.

Um traço decisivo para a afirmação do Estado é o equilíbrio dinâmico entre a lei e a ordem, de um lado, e a ação política dos cidadãos "livres" num dado território, do outro. Daí que, no quadro democrático, o Estado seja, por excelência, o terreno da política, o qual, aliás, só tem sentido enquanto espaço plural, de liberdade, de diálogo, de compromisso e de conflitualidade. Prende-se com isso a permanente tensão entre a atividade "interna" do Estado e a sua atividade "externa", sendo que o termo "interna" tanto pode referir-se à esfera das suas próprias instituições como ao território nacional, enquanto a dimensão "externa" pode remeter quer para a ação diplomática e da defesa perante os inimigos exteriores, quer para a esfera que fica de fora do sistema político-jurídico-administrativo do Estado, isto é, para a sociedade civil. Deste modo, faz sentido afirmar que a eficácia do Estado se mede não tanto pelo seu funcionamento interno, mas bem mais pelo maior ou menor sucesso na relação que estabelece com o que lhe é exterior. Por isso, as alianças, os jogos de poder e a ação estratégica que definem os atores da arena politica que operam no seio do Estado ou em relação direta com ele, os levam a lutar permanentemente por reforçar e reinventar as suas fontes de legitimidade política através da persuasão e do compromisso em torno de interesses (taticamente) comuns. Como afirmou o autor de O Contrato Social, "o forte nunca é suficientemente forte para ser sempre o senhor, a menos que transforme a força em direito e a obediência em dever" (ROUSSEAU, 2000 [1762]).

Para Weber, o Estado é, por definição, a esfera da política e das instituições da governação, que devem - através da lei - prevenir o risco de excessivo intervencionismo na economia e na sociedade. Sendo o detentor no monopólio da violência legítima, deve velar pela ordem social (legítima), promovendo os meios legais para regular os conflitos, revertendo-os em "lutas pacíficas", isto é, criando uma saudável competição individual que leve a sociedade a premiar os mais aptos, dando lugar a um sistema estratificado que reflita a distribuição diferencial do poder. Assim, o Estado social emergente não 
deveria exceder os limites de um "Estado regulador", ou seja, assumir-se como o principal garante do modelo liberal. Compete ao Estado e ao mercado desenvolver e aperfeiçoar a racionalidade, promovendo leis e formas administrativas assentes em sistemas impessoais e burocráticos capazes de consolidar essa mesma ordem, sendo esta apoiada em formas legítimas de consentimento - fundadas na tradição, na legalidade ou no carisma do líder - e não na coerção. $\mathrm{Na}$ perspetiva weberiana assume particular importância o papel dos funcionários e técnicos, especializados na gestão do direito formal que o Ocidente apropriou do legado do império romano e que influenciou a burocracia estatal moderna, sem a qual o capitalismo não poderia consolidarse. O aumento da complexidade a isso obrigava, se bem que Weber reconhecesse os problemas daí advindos para o funcionamento da democracia. Entre outros, o autor de Economia e Sociedade assinala a crescente tensão entre soberania crescente (controlo dos governos pelos governados) e soberania decrescente (controlo dos governados pela burocracia), enquanto fatores favoráveis à emergência de um duplo perigo: a "jaula de ferro" da administração e as ações emotivo-passionais instigadoras de novos poderes carismáticos (SANTOS; AVRITZER, 2003, p. 41).

Já Durkheim (1983), preocupado com a ordem moral e a integração dos indivíduos numa sociedade caracterizada pela "solidariedade orgânica", considerou o Estado como inerente ao caráter complexo e plural das sociedades "políticas", ou seja, ele só existe em sistemas diferenciados cuja composição interna agrega distintos grupos secundários. Impõe-se enquanto autoridade, não pela força, mas através da moralidade, instigando os indivíduos a participar, sobretudo através do associativismo corporativo, no exercício das profissões, na edificação de uma normatividade onde o coletivo tem a primazia sobre o individual sem, no entanto, oprimir os indivíduos. O Estado é então "a sede de uma consciência mais elevada" que, sem se confundir com a coletividade mais geral, constitui o seu sistema nervoso central, "o órgão encarregado de elaborar certas representações que valem para toda a 
Portugal e o Estado Providência | Elísio Estanque

coletividade, que se distingue das outras representações coletivas pelo grau mais elevado de consciência e reflexão".

Se o Estado veio a conquistar uma tão evidente centralidade no mundo ocidental - e em especial na Europa - foi não apenas por via do seu papel político, mas, sobretudo porque a economia de mercado, que dominou as sociedades industriais a partir do século XIX, deu lugar a fortíssimas rupturas sociais e conduziu a um desmantelamento violento das velhas formas de organização econômica e de coesão cultural das comunidades tradicionais. A economia das sociedades humanas está submersa em relações sociais, como afirma Polanyi (1980), e a produção era nas sociedades tradicionais uma função direta da organização social, a qual desenvolveu as suas atividades e relações de troca na base dos princípios da reciprocidade, da dádiva e da redistribuição, e onde a ideia de lucro ou mesmo de riqueza, do ponto de vista individual, estiveram ausentes. Todavia, foi justamente o dominio avassalador do princípio do mercado que fez despoletar a necessidade social de mecanismos de regulação, a fim de minimizar ou prevenir os excessos do capitalismo selvagem que nessa época se instalou na Europa, em especial em Inglaterra. Daí o paradoxo do Estado, tendo em conta que - como ilustram as ideias de Rousseau - o mesmo vive há vários séculos no dilema de lutar pela realização da comunidade política ao mesmo tempo em que se debate com a crescente fragmentação das identidades coletivas de base local, dando lugar, não poucas vezes, ora a formas elitistas de democracia mitigada, com escassa participação popular, ora a regimes nacionalistas onde as massas se tornaram mera força instrumentalizada por chefes autoritários. O sonho de construção de uma comunidade politica alargada para niveis que recuperassem o velho sentido (rousseauniano) da comunidade natural foi uma utopia por cumprir, mesmo depois da experiência europeia do contrato social, apesar desta ter sido a fórmula que - na vigência do Estado-providência - mais se aproximou da referida utopia (MORRIS, 1996).

Se a atividade econômica é sempre social, tal não invalida reconhecer-se a distinção analitica entre os dois domínios. Para além das implicações 
reciprocas entre economia e sociedade, trata-se de dimensões que encerram tensões e lógicas conflituantes, sobretudo se a esfera econômica é dominada pelo princípio do mercado. Na verdade, uma análise mais abrangente do papel do Estado que nos permita uma abordagem integrada do seu significado social e político requer um esforço de reflexão em que tais princípios se façam presentes.

Embora os marxistas tenham olhado para o Estado capitalista principalmente como "superestrutura" - expressão de uma realidade econômica fundada em relações de classe e formas de exploração - a visão estruturalista e dicotômica perdeu atualidade à medida que novos desenvolvimentos teóricos foram surgindo, inclusive no seio do campo marxista, por exemplo, a partir dos contributos de Nikos Poulantzas. Nesta linha de reflexão, é consensual a ideia de que o Estado tem como principal função societal, no capitalismo, organizar as classes dominantes enquanto "bloco-no-poder", conferindo coerência e aproximando os diferentes interesses entre frações específicas da burguesia, função essa que só pode ser cumprida na medida em que a "relativa autonomia" das instituições seja assegurada. Dito de outra forma, para que o Estado consiga cumprir tal desígnio, isto é, para realizar a sua função reprodutiva e assegurar a coesão da ordem socioeconômica vigente, terá de se afirmar "acima" de cada fração e sempre que necessário agir em beneficio (real ou aparente) do povo e das classes trabalhadoras, por exemplo, legislando contra os interesses (imediatos) dos grupos privilegiados. É em larga medida devido à atividade redistributiva do Estado que a sua função ideológica e discursiva ganha eficácia no apaziguamento da conflitualidade social e consequente preservação do status quo. Efetivamente, o Estado só pode assegurar a sua força política enquanto controlar ou regular a riqueza econômica produzida na sociedade, em particular ao assegurar as condições de crescimento e acumulação de riqueza que sustente a política fiscal de que depende. Importa, por isso, recusar a noção de absoluta autonomia ou de mera instância normativa para o Estado moderno. 
O Estado tem um fundamento econômico, enquanto a economia tem um fundamento político (BURAWOY, 1985; 2010). Por um lado, o fundamento econômico refere-se à sua capacidade política para intervir na economia. Por outro lado, a economia tem um fundamento politico no sentido em que o modo como cada um dos agentes econômicos participa no sistema produtivo (e no mercado) obedece a relações de poder e de dominação orientadas por critérios e formas de retribuição e de recompensa profundamente desiguais, mas suportadas por lógicas de consentimento que naturalizam as desigualdades e formas de exploração. Em suma, é na sua tripla função - econômica, ideológica e política - que o Estado realiza o seu papel de produção e de revitalização permanente dos ingredientes que cimentam a sociedade no seu conjunto. Todavia, esse é um trabalho que está longe de ser isento de contradições.

Se bem que, em Poulantzas (1978), o Estado constitua a "ossatura" da sociedade e funcione como o "destilador" da luta de classes, o mesmo autor não deixa de identificar no seu seio as inevitáveis tensões e conflitos inscritos nos jogos de poder e nas alianças que os seus agentes permanentemente promovem, seja de dentro para fora seja de fora para dentro. Trata-se de um sistema onde as componentes institucional, formal e jurídica podem esconder uma parte das relações e disputas concretas que circulam no seu seio, ou seja, pode falar-se, em certos contextos, como já foi apontado no caso da sociedade portuguesa, de um Estado dual ou Estado paralelo (SANTOS, 1990, 1994), que tanto atua por ação como por omissão na sua articulação tensa e complexa com a sociedade, na sua função simultaneamente reguladora, normativa e de dominação. A linguagem e os rituais do Estado são sempre adornados com as vestes mais coloridas, evidenciando desse modo a sua vocação ideológica, usando reiteradamente as formas cerimoniais e os meios discursivos de comunicação ao seu dispor para dissimular ou esconder perante os olhares públicos as tramas que operam paralelamente nos subterrâneos dessa teia densa e labirintica de instâncias e de interesses que alimentam o Estado ou dele se alimentam (POULANTZAS, 1971, 1978; BURAWOY, 1985; RUIVO, 1999). 


\section{Sociedade, mercado e Estado social}

A partir de formulações desenvolvidas por Boaventura de Sousa Santos (1994), pode considerar-se que o Estado, o mercado e a comunidade constituem princípios centrais na organização das sociedades ao longo da modernidade, jogando a sua articulação um papel dinâmico na organização do sentido histórico que, em momentos diferentes, marcou as sociedades europeias nos últimos duzentos anos. Tais dinâmicas são, portanto, expressão das contradições estruturais que em contextos particulares - e sob a forma de políticas governativas, movimentos sociais, lutas de classe ou outras forças organizadas - assumem orientações concretas, empurrando por assim dizer a sociedade ora numa direção progressista e emancipatória (melhorando os padrões de vida e bem-estar dos seus cidadãos), ora para a reprodução e reforço de opressões e injustiças sociais (prolongando os fatores de atraso ou regredindo nos seus padrões de desenvolvimento).

Segundo Polanyi (1980), a chamada economia "de mercado" só se tornou dominante no pós-Revolução Industrial, tendo na verdade a Europa do século XIX assistido a um domínio avassalador do mercantilismo, que, ao longo da fase mais "selvagem" do capitalismo moderno obrigou à construção de mecanismos de regulação, designadamente através do Estado. Quer isto dizer que - em contracorrente com o pensamento econômico neoliberal que dominou o mundo desde os anos oitenta do século passado - o papel dos "mercados", como entidades ou "forças" capazes de se imporem às sociedades, foi sempre rejeitado pelos modelos tradicionais de organização econômica nas sociedades de economia agrária e nas culturas rurais, pelo que, como aconteceu no século XIX, o liberalismo desregulado gerou compreensiveis resistências sociais e politicas, pressionando os governos e as instituições públicas a criar meios para limitar e regular os excessos do mercantilismo.

É neste quadro que importa situar o problema a fim de compreendermos alguns dos fundamentos sociológicos do Estado social na Europa e as razões por que a sua eventual extinção ou falência significaria um golpe profundo nas expectativas dos cidadãos europeus (como adiante veremos), cujas 
consequências poderiam ser devastadoras. O Estado, enquanto relação de forças condensada veste-se das roupagens do positivismo durkheimiano para produzir normatividade e ao mesmo tempo cria uma ficção de unidade, a “comunidade imaginada" (ANDERSON, 1991), usando os seus diferentes aparelhos e politicas para promover formas duradouras de consentimento, seja através da ação e do discurso, seja através de opacidades e silêncios seletivamente controlados. Os seus objetivos passam, portanto, por tentar conjugar três dimensões fundamentais: a) o património histórico, cultural e linguístico do respetivo território onde é o garante da soberania; b) as experiências, identidades, interesses de classe, lutas e conflitos do passado e do presente; e c) a organização social e institucional concreta, imprimindo-lhe uma estratégia racional e um projeto de futuro (BURAWOY, 1985). Acresce que estas dimensões, nas suas diferentes conjugações, dão lugar em cada momento histórico a formas e regimes de regulação particulares que é necessário entender numa perspetiva dinâmica.

Nos últimos duzentos anos é possivel conceber a existência de diversos regimes de acumulação. Numa primeira fase, um regime despótico, de mercado, que vingou no período de capitalismo "selvagem", suscitando respostas e movimentos sociais anti-sistémicos, com destaque para o movimento operário e para as convulsões e movimentos republicanos, anarquistas e socialistas que assumiram uma força decisiva na viragem do século XIX para o século XX. Entretanto, a consolidação de novas técnicas e racionalidades burocráticas aplicadas à economia conduziu ao aperfeiçoamento de um regime disciplinar na produção, caracterizado pela rápida acumulação e crescimento (modelo taylorista), o que, apesar disso, não evitou a grande instabilidade social e politica que passou por intensos conflitos, guerras e revoluções na primeira metade do século XX. Só posteriormente, já no período do pós-guerra se afirmou um regime hegemônico, coincidente com o advento do welfare state, no qual a integração e o consentimento foram objeto de uma negociação e compromissos sociais realizados à sombra do fordismo e das políticas sociais promovidas pelo Estado. Finalmente, desde a década de 80 do século passado, 
assistimos a uma nova viragem, de sentido liberal, mas agora em escala global, o que leva a que se fale da emergência de uma nova forma de despotismo, o despotismo global ou despotismo hegemônico, coincidente com as últimas décadas de hegemonia neoliberal, em que a regulação se realizou através das múltiplas conexões transnacionais dinamizadas pela globalização e pelo capitalismo financeiro, apoiados nas redes informáticas e nas novas tecnologias da comunicação (BURAWOY, 1985, 2001; CASTELLS, 1999).

Pode, pois, afirmar-se que ao longo dos últimos três séculos aqueles regimes operaram sobre os despojos da velha sociedade pré-industrial onde eram as estruturas sociais - ou mais corretamente, da comunidade - que comandavam a economia. Na linha de autores já referidos (SANTOS, 1994; POLANYI, 1980), pode dizer-se que o modo como se combinaram ao longo de todo este tempo dependeu sempre da forma como os principios da comunidade, do mercado e do Estado se foram estruturando na geometria do território e na organização coletiva das sociedades e das nações. Com maior ou menor articulação entre os princípios do Estado, do mercado e da comunidade (SANTOS, 1994; 2011) permaneceu uma constante tensão na qual se inscreveram os processos de sentido mais progressista e emancipatórios ou o seu contrário, as forças mais normalizadoras ou sistemas mais conservadores e autoritários. Até finais do século XIX foi o princípio de mercado que se sobrepôs aos restantes, mas o mesmo induziu - sobretudo devido ao papel da luta de classes - um esforço de reconstrução do princípio da comunidade. O movimento operário e as ideologias mais radicais que o penetraram (em especial o anarquismo e o marxismo) foram portadores de uma linguagem, de um projeto politico que, de certo modo, transportaram um reforço do princípio da comunidade ou, dito de outra maneira, projetaram um discurso classista e comunitarista que, além da sua marca emancipatória, reinventaram a identidade colectiva dos oprimidos em torno da noção de classe. Ainda que em parte ficcionada, essa foi uma subjetividade que, por um lado, resistiu ao princípio do mercado e, por outro lado, foi decisiva para a emergência do Estado social. Tal processo acabou por conduzir à primazia do princípio do 
Portugal e o Estado Providência | Elísio Estanque

Estado sobre os princípios do mercado e da comunidade, tornando-se hegemónico, em especial após a II Guerra Mundial, com o triunfo e consolidação do Estado-providência. Mas, como é sabido, a partir da década de setenta foi de novo o mercantilismo que se reergueu e, desde então, é novamente o princípio do mercado que ganha hegemonia e o Estado que recua e os seus programas sociais, assistenciais e solidários - e se tem vindo a submeter cada vez mais à economia de mercado, agora numa escala mais ampla, sob a batuta da globalização neoliberal.

Em diversos momentos desde o nascimento das sociedades industriais modernas, mas em especial nas últimas quatro décadas, os mercados cresceram de uma forma avassaladora, mantendo a sua oposição ao protagonismo estatal. Se, durante muitos séculos, os mercados foram apenas acessórios dos sistemas sociais, agora passou a ser a produção e distribuição que viriam-se submetidas cada vez mais aos mercados e as transações monetárias e a motivação pelo lucro ganham primazia sobre as relações de troca e a reciprocidade. Até certo ponto, a sociedade no seu conjunto regressa à situação que já experimentara no século XIX, isto é, a uma sujeição generalizada às leis do mercado. Segundo Polanyi, o trabalho, a terra e o dinheiro, sendo parte do sistema econômico, são organizados através do mercado, mas não são mercadorias dado que nenhum deles foi criado para venda pelo que "a descrição do trabalho, da terra e do dinheiro como mercadorias é inteiramente fictícia" (POLANYI, 1980, p. 85). Sendo uma tendência antiga, que remete aos finais do século XVIII, não há duvidas que o recrudescimento do princípio do mercado como ideologia dominante suscitou algum paralelismo com o que aconteceu na Europa desde há duzentos anos, levando a economia de mercado a ganhar ascendente sobre as atividades produtivas de base comunitária e solidarista (LAVILLE; ROUSTANG, 1999).

O campo laboral é sem dúvida aquele em que os impactos desestruturadores da globalização têm sido mais problemáticos. As consequências disso mostraram-se devastadoras para milhões de trabalhadores de diversos continentes. E a Europa é o continente onde as alterações em curso 
representam o mais flagrante retrocesso perante conquistas alcançadas, desde o século XIX. Com efeito, os impactos da globalização têm vindo a induzir novas formas de trabalho cada vez mais desreguladas, num quadro social marcado pela flexibilidade, subcontratação, desemprego, individualização e precariedade da força de trabalho. Assistiu-se a uma progressiva redução de direitos laborais e sociais, e ao aumento da insegurança e do risco, num processo que se vem revelando devastador para a classe trabalhadora e o sindicalismo desde os finais do século XX (CASTELLS, 1999; BECK, 2000; ANTUNES, 2006).

Embora se saiba que não existe um modelo europeu único, pode-se genericamente, considerar que, ao longo do chamado modelo fordista, os traços que guiaram as principais economias europeias passaram por um equilibrio entre o Estado e o mercado, conjugado com um contínuo crescimento econômico com politicas econômicas keynesianas de procura do pleno emprego e um equilíbrio entre a produção industrial e a redistribuição. Tal sistema estimulou o aumento do poder de compra e a sustentabilidade das políticas de segurança e proteção social, configuradas no Estado-providência, que se apresentou ao mundo como o principal modelo de sucesso econômico e de bemestar geral. O Estado-providência europeu tornou-se uma espécie de contraparte do modelo de "socialismo soviético", um e outro com pretensões a servir de "farol" de progresso e emancipação dos trabalhadores e da humanidade, ao longo do período entre 1945 e 1975, por isso mesmo já batizado pelos "gloriosos trinta anos" de bem-estar social.

A Europa (particularmente os países da região Norte) reunia as vantagens dos EUA com todos os seus avanços tecnológicos e cultura democrática com politicas sociais protetoras dos mais desapossados. Efetivamente a relação salarial fordista de produção, generalizada no pós-guerra - embora, evidentemente segundo dinâmicas nacionais muito distintas consoantes às regiões e aos regimes de cada país -, é indissociável do papel do Estado, pois ela traduziu a passagem de uma relação de trabalho concorrencial e puramente mercantil para um modelo juridicamente regulado, dando lugar à ideia de que: “a garantia de emprego e a noção de emprego - o contrato indeterminado - e a 
Portugal e o Estado Providência | Elísio Estanque

proteção social estão na origem da chamada cidadania social na Europa ocidental do pós-guerra” (OLIVEIRA; CARVALHO, 2010, p. 27).

O choque petrolífero de 1973-74 provocou receios sérios de uma doença súbita e preocupante para a Europa: a "euro-eslerose", relacionada com a perda de confiança no modelo e seu futuro prospetivo (CRAVINHO, 2007), já então com as economias asiáticas em pano de fundo, mostrando os primeiros riscos de desmantelamento do modelo e dando lugar a um discurso que passou a secundarizar o papel das empresas e da indústria em beneficio da economia financeira e do monetarismo. O olhar passou a centrar-se, na perceção comum, “quase exclusivamente no lado social do modelo, representado pelo Estado social, acompanhado pelas políticas de redistribuição financiadas pela elevada taxação" (CRAVINHO, 2007, p. 14). Esta leitura assentava na ideia de que o desempenho econômico da Europa era francamente deficitário por referência aos EUA e, ao que se supunha, por maioria de razão o seriam perante as economias emergentes do continente asiático assentes nos baixos salários. A crescente pressão que se foi exercendo sobre as atribuições sociais do Estado fortemente potenciadas pelo triunfo político do modelo neoliberal consubstanciado nas vitórias de Ronald Reagan e Margaret Tatcher - deu lugar a novas fórmulas e propostas para a redução da intervenção estatal na economia, suscitando novas linhas de argumentação em que o chamado "princípio da subsidiariedade", isto é, a ideia de restringir ao mínimo indispensável a intervenção do Estado, quer na atividade empresarial quer em programas assistenciais, apenas se justificava enquanto complemento da sociedade e dos agentes econômicos, ou seja, apenas nos casos em que a iniciativa privada se revelasse incapaz de cumprir as funções consideradas fundamentais para o interesse público.

Como apontado anteriormente, os modelos "sociais" ou de regulação que marcaram a Europa passaram por ciclos muito distintos e revelaram tensões e conexões muito complexas, não obstante a presença dominante de uma dada fórmula em relação a outras. Nesse processo, sempre oscilaram tendências contrárias ou complementares entre a primazia dos mercados e a do Estado. É 
importante não esquecer que o que ocorreu no continente europeu e no Ocidente em geral não foi, de modo nenhum, um processo uniforme e simultâneo em todos os países. Muito embora a economia de mercado tenha começado a aumentar a sua força perante os Estados soberanos (o desequilíbrio de poderes, a força politica, militar, tecnológica etc., de cada Estado), bem como a solidez das suas instituições e o nível geral de qualificações e capacidade competitiva no xadrez internacional, daí resultaram dinâmicas muito discrepantes. Podem, por exemplo, fazer-se distinções muito claras entre o modelo das sociais-democracias vigente nos países nórdicos, a tradição corporativista de países como a Alemanha, a França e a Itália e o modelo mais liberal vigente no Reino Unido (e nos EUA), sendo necessário destacar que, já desde os anos noventa se vem colocando em causa a ideia de que o modelo neoliberal seja o desenlace inevitável da crise do Estadoprovidência (JESSOP, 1993; ESPING-ANDERSEN, 1996; SANTOS; FERREIRA, 2001). Não se trata, portanto, de pensarmos em termos de uma simples viabilidade ou inviabilidade do "Estado social", mas antes no quadro das transformações socioeconômicas e politicas mais profundas que marcam a mudança histórica, em particular nos últimos dez anos. Sendo o capitalismo um sistema dotado de grande complexidade e dinamismo, o modo como a sua infraestrutura econômica se combina com o sistema democrático (a democracia formal) tem obedecido sempre a contradições e compromissos mais ou menos instáveis, sendo hoje duvidoso até quando e em que condições a democracia e o capitalismo constituem um binômio compativel ao crescimento das forças produtivas ou se, pelo contrário, intensificam os seus antagonismos e nos conduzem a ruturas radicais e imprevisiveis (SANTOS, 2005, 2011). Seja como for, a história mostra-nos que não há modelos monolíticos que se seguem uns aos outros, mas sim soluções sempre compósitas, transitórias e de duração indefinida.

Num período como o que temos vivido nos últimos anos no contexto europeu, de atrofiamento do welfare state, vimos como o modelo keynesiano foi deixando espaço para, de novo, reemergir um conceito de "Estado regulador", 
inspirado no princípio shumpeteriano segundo o qual os mercados são dotados de uma capacidade "natural" de autorregulação, cabendo ao Estado, sobretudo, assegurar as condições da boa concorrência. Essa passagem, apesar das suas particularidades em países diferentes, traduziu-se em três traços fundamentais: a descentralização da ação estatal para as escalas local ou transnacional; a maior focalização na esfera laboral, nomeadamente nas políticas de formação profissional e na flexibilização (lean production); a aposta na "governança", em geral acompanhada por processos de privatização e subcontratação em diversos setores e serviços públicos (SILVA, 2009).

$O$ que vem sucedendo na Europa nas últimas décadas prende-se igualmente a um conjunto de processos e tendências extremamente diversas, apesar de se tratar de transformações arrastadas pelas mesmas forças que têm fustigado as economias e os Estados desde os anos oitenta do século passado. O fraco crescimento e a recessão econômica, o défice público, o endividamento externo e o envelhecimento demográfico são alguns dos aspectos que tornaram insustentável o modelo de Estado social na maioria dos países europeus e estão a empurrar alguns para a ruína.

Nestas condições, parece evidente a impossibilidade de um regresso à velha matriz do Estado-providência tal como existiu no passado. As opções políticas a adotar terão de escolher entre a intensificação do mercantilismo "selvagem", correndo o risco de fazer explodir as desigualdades, a miséria e as injustiças sociais, com a consequente generalização da conflitualidade, ou dar continuidade à tradição humanista e solidária inscrita na história da Europa, reerguendo um modelo social adequado à nova realidade. Perante o agravamento da atual crise, o modelo neoliberal (ainda hegemônico) perdeu legitimidade em face dos resultados desastrosos do poder financeiro e do mercantilismo global, o que, associado às incongruências das politicas da UE, colocou perigosamente em causa o projecto europeu e conduziu alguns dos Estados mais antigos (como Portugal e a Grécia) em risco de falência e perda de soberania. Por isso aumentam a cada dia que passa as vozes a diagnosticar a crescente fragilidade da própria democracia liberal representativa, embora se 
trate de um risco que pode ser travado a tempo, como consequência de uma previsível repolitização da sociedade - cujos indicios já começam a surgir nomeadamente através do revigoramento dos movimentos sociais -, dinamizando novas modalidades de ação e abrindo novas perspetivas de exercício de cidadania. Filipe Carreira da Silva sugere um cenário de recriação da fórmula antiga, referindo-se a um "Estado neo-social", cenário que, a confirmar-se, passará pela emergência de um novo paradigma que poderá inspirar-se, "quer em ideologias do passado, entretanto reformuladas, quer híbridas mais ou menos consistentes, quer até em propostas realmente originais [que] poderão vir a ser esgrimidas no espaço público num futuro mais próximo do que muitos julgariam possiveis apenas há uns meses atrás" (CARREIRA DA SILVA, 2009, p. 38). Seja como for, o caso português oferece-se como um exemplo particular, um case study que merece ser pensado à luz das suas especificidades.

\section{Portugal e o Estado social}

A valorização do Estado social por parte dos europeus e dos portugueses é inquestionável, mas a sua importância reflete ao mesmo tempo as debilidades estruturais da sociedade portuguesa. Essa é uma realidade que pode ser observada quer no plano concreto, quer no plano das representações subjetivas. Como se sabe, em Portugal o Estado-providência surgiu muito tardiamente e não chegou a atingir uma robustez que o situasse num padrão semelhante ao que vigorou nos países do norte da Europa. A industrialização tardia e a fragilidade de uma economia pequena e atrasada, sob o controlo apertado de um regime repressivo e avesso a qualquer modernização, ou seja, a condição periférica em que nos encontramos, teria de constituir um quadro de dificuldades acrescidas para os projetos de desenvolvimento que o país pretendeu abraçar em 25 de Abril de 1974. Sem esquecer o entusiasmo coletivo e a importância das experiências de democracia participativa no período revolucionário - num contexto em que a fragilidade ou paralisação das instituições do Estado abriu espaço para projetos de mobilização, 
associativismo e cooperação entre trabalhadores, moradores, sindicatos, etc. -, nomeadamente no próprio desenhar dos contornos do modelo de Estado social que posteriormente se procurou edificar, o certo é que as condições socioeconômicas do nosso país não foram as mais favoráveis. No início da década de oitenta, quando o nosso Estado-providência começou a ser construído, estávamos ainda a "digerir" a ressaca da utopia revolucionária, que ficcionamos tão rápida como ingenuamente. Então, uma parte dos atores políticos com maiores responsabilidades na governação presumiu que o crescimento econômico seria imparável e que, portanto, as politicas públicas teriam uma sequência de natural consolidação rumo a um "socialismo democrático" onde as políticas redistributivas poderiam satisfazer os cidadãos, levando o país a recuperar em poucos anos o atraso ancestral que tinha. A outra parte foi mais cética quanto às virtudes do Estado na economia e estimulou ao máximo a iniciativa individual e o papel do mercado, muito embora nunca deixasse de controlar os recursos públicos para satisfazer as suas clientelas e permanecer senão no governo, pelo menos na zona de influência (e de "alternância") que permitisse manter algum poder e beneficiarse dos recursos público em cada novo ciclo político. Em todo o caso, o que importa destacar é que, dadas as circunstâncias históricas e sociopolíticas em que se iniciou o processo de construção do nosso Estado social, ele surgiu já em contraciclo com o que estava a ocorrer nos países europeus avançados. Com duas agravantes: não tínhamos nem uma cultura democrática consolidada nem um potencial econômico e tecnológico que garantissem de facto um ciclo de crescimento que nos aproximasse desses países.

A adesão à Comunidade Econômica Europeia (atual UE) constituiu, na verdade, um impulso importante que, objetivamente, estimulou os inegáveis avanços que em todas as áreas sociais alcançámos nas últimas três décadas. No entanto, e em contrapartida, a "promessa" da Europa e a ficção montada pelo discurso dominante levaram os portugueses a crer que, com a entrada dos fundos estruturais, com a competência "técnica" que o Primeiro-Ministro de então, Cavaco Silva e a sua entourage e as condições internacionais favoráveis, 
iríamos, enfim, por um lado, corrigir os excessos e aplacar o sonho socialista e, por outro, meter nos carris uma economia que nos traria o sucesso e o bemestar, desde que mostrássemos ser "bons alunos” perante a Europa. Apaziguar a contestação e apostar nas oportunidades e nas carreiras individuais, deixando-nos guiar por um professor de inquestionável competência seria pretensamente a condição infalivel para atingir "o pelotão da frente". Muito embora sejam inegáveis os resultados da primeira década após a adesão - tanto no plano do crescimento como nas infraestruturas e na melhoria de muitos indicadores "sociais" -, as contradições e injustiças sociais não terminaram, obviamente, assim como não terminaram as ilusões acerca do potencial do "Estado-de-recursos-ilimitados", enquanto as "reformas estruturais" permaneceram eternamente adiadas até aos dias de hoje.

Seja como for, um aspeto que não pode ser ignorado é a especificidade da sociedade portuguesa nesta matéria, revelando muitas vezes formas próprias de conjugação e mistura entre lógicas institucionais e sociais, que noutros países desapareceram há muito. Por exemplo, o fenómeno da "economia solidária" muitas vezes também designada por "terceiro sector", "sector não lucrativo", "economia comunitária", "economia civil" ou "economia de comunhão" -, tem desempenhado no nosso país um importante papel no plano das sociabilidades ou solidariedades "primárias", conjugando o Estado, o mercado e a comunidade, onde o social e o econômico se misturam, abrindo espaço a formas alternativas de organização produtiva e deste modo escapando do modelo econômico imposto pela exclusiva racionalidade capitalista (RAMOS, 2011, p. 83). Mesmo admitindo que o Estado-providência português não chegou a passar de um "semi-Estado-providência", a sua relativa eficácia reguladora e distributiva (pelo menos até aos anos 90) ficou a dever-se ao modo como as dinâmicas da sociedade minimizaram as lacunas e a fraqueza do Estado enquanto instância providencial. Assim, cito de novo Boaventura de Sousa Santos para retomar a sua ideia de que a capacidade de aceitação e a ausência de ruturas e conflitos fortes na nossa sociedade justifica em parte a ineficiência ou carências das prestações públicas - em especial nessa primeira 
fase - foi suprida por uma providência enraizada na própria sociedade, isto é, "em Portugal, um Estado-providência fraco coexiste com uma sociedadeprovidencia forte" (SANTOS, 1994, p. 46).

Ainda que este possa ser um tópico controverso, vem a propósito salientar a importância das subjetividades, no sentido em que, como refere o mesmo autor e eu próprio subscrevo, as condições em que esta promessa de uma "boa sociedade" foi assimilada pela consciência colectiva dos portugueses, a ideia de um processo em marcha segura rumo aos padrões de vida europeus mais avançados da época, reforçou significativamente os niveis de aceitação e de tolerância perante as dificuldades, tornando-as suportáveis na medida em que foram vividas como transitórias, o que ajudou a "despolitizar" parte dos problemas uma vez que sucessivas medidas menos populares podiam ser justificadas como inevitáveis, em nome das exigências da integração europeia. Deste modo, a forma política do Estado poderia ser considerada um "Estadocomo-imaginação-do-centro" (SANTOS, 1994, p. 51).

\section{Estado e políticas sociais: as atitudes dos portugueses}

Os traços acima referidos, apesar de contraditórios, não nos impedem de assinalar, como já foi apontado, o efetivo crescimento do Estado e das políticas sociais em Portugal, quer no período do pós-25 de Abril de 1974, quer ainda durante o Estado-Novo. O emprego público, por exemplo, revelou, desde os anos sessenta, uma tendência de crescimento constante até ao início dos anos noventa, nomeadamente, como assinalou João Freire, no que se refere ao pessoal ligado às funções sociais do Estado, sobretudo nos setores da educação e da saúde, um aumento anterior à referida data histórica, o que ilustra o quão antigo é esse processo. Porém, o volume de funcionários nesses setores era baixo até finais da década de setenta (cerca de $20 \%$ do total da administração pública), tendo crescido muito rapidamente nas décadas seguintes (cerca de 68\% da administração pública) e mantendo-se estável até 2008 (ROSA; CHITAS, 2010; FREIRE, 2011). 
O número total de assalariados na administração pública rondava os 523.119 em 2009. Desde 2005 que esse valor tem diminuido, tendo o setor público perdido pessoal de forma muito significativa, sobretudo entre 2005 e 2010, com uma redução de cerca de 80.000 funcionários. Consequentemente, e como mostram os dados mais recentes, as despesas com o pessoal da administração pública em Portugal decresceram muito significativamente. Por comparação com a média dos países da UE27, "o peso das remunerações da administração pública no PIB para Portugal traduz variações negativas de 10,1\% em relação ao ano 2000 e de $11,8 \%$ em comparação com o ano 2005; enquanto o mesmo indicador para a média dos países da UE apresenta variações positivas de 4,8\% relativamente a 2000 e de 2,4\% em comparação com 2005” (BOEP, 2011, p. 1). É claro que o peso relativo da administração pública tem sido apontado, desde há pelo menos uma década, como a principal causa do agravamento da despesa pública e do respetivo défice, com isso justificando um vasto conjunto de medidas (adotadas pelos últimos governos) no sentido de reformar o Estado, tendência que, como é sobejamente conhecido, se tem vindo a agravar com o aproximar da crise e da austeridade que enfrentamos neste momento.

Para além do peso relativo do Estado social na economia, importa referir outros indicadores, nomeadamente os que consideram as atitudes subjetivas dos cidadãos. Algumas das bases de dados recolhidas periodicamente nos países da UE e em Portugal permitem atestar a centralidade que o Estado social ocupa nas representações das pessoas, permitindo-nos daí induzir os impactos reais das políticas sociais. Por exemplo, no último inquérito do European Social Survey (ESS) - que permite comparar dados de quatro inquéritos, de 2002 a 2008 (VALA et al., 2010) -, fica clara a importância atribuída pelos inquiridos à responsabilidade social do Estado, visto que, na média dos países considerados ${ }^{4}$

\footnotetext{
4 Os países abrangidos pelos estudos do European Social Survey (ESS) foram 34, embora nalguns deles o inquérito não tenha sido aplicado em todos os anos em que ocorreram os levantamentos: Alemanha, Áustria, Bélgica, Bulgária, Chipre, Croácia, Dinamarca, Eslovénia, Eslováquia, Espanha, Estónia, Finlândia, França, Grécia, Holanda, Hungria, Irlanda, Islândia, Israel, Itália, Letónia, Lituânia, Luxemburgo, Noruega, Polônia, Portugal, Reino Unido, República Checa, Roménia, Rússia, Suécia, Suiça, Turquia e Ucrânia.
} 
(excepto Portugal) atribuem uma importância média de 7,7 , na escala entre 0 (mínima) e 10 (máxima). No caso português a classificação é de 8,12 na mesma escala, colocando Portugal no grupo dos que atribuem maior importância ao papel do Estado social. Vale a pena ainda referir outros aspetos mais específicos e igualmente relacionados com o funcionamento das instituições estatais. Por exemplo, os niveis de satisfação dos cidadãos perante a vida em geral e perante as políticas, as instituições e a democracia; ou as atitudes perante o estado da educação e dos serviços de saúde.

Assim, os resultados do ESS (medidos na escala de $0=$ extremamente satisfeito e 10 = extremamente insatisfeito) revelam que ao longo da primeira década do presente século os portugueses se mostraram moderadamente satisfeitos com as suas condições de vida, mas com percentagens de satisfação claramente abaixo da média dos países da UE, resultados que se acentuam quando comparados com os países nórdicos (VALA et al., 2010). No caso da situação econômica do país, os niveis de insatisfação são bem mais evidentes e com tendência para o agravamento à medida que foram sendo recolhidos os sucessivos resultados dos quatro inquéritos aplicados ao longo da década. Quanto ao grau de satisfação sobre a atuação do governo, os resultados oscilaram um pouco ao sabor dos ciclos politicos (com maiores índices de insatisfação nos anos de 2002 e 2008), mas de um modo geral evidenciaram avaliações negativas mais acentuadas do que a média da amostra, sendo que o somatório de percentagens negativas (entre 0 e 4) ou se aproximam ou superam os $50 \%$, atingindo os $64,2 \%$ no ano de 2004 e os $66,6 \%$ em 2008. Esta desconfiança do governo só é superada quando se trata de avaliar o grau de confiança nos "políticos". Neste caso, somando os valores negativos (entre 0 e 4 da escala), obtemos para 2004 uma percentagem de 76,6\% e para 2008 de $81,2 \%$, além de que os resultados negativos são bem mais acentuados em Portugal do que na média dos restantes países. Refira-se ainda, a propósito da fraca confiança na "classe política", que o indicador "nenhuma confiança" obteve em 2002 uma percentagem de 17,2\% de respostas (contra 11,8\% da média dos outros países), evoluindo depois para 25,3\%, 25,7\% e 29,4\% 
respetivamente nos anos 2004, 2006 e 2008, mantendo-se cerca de dez pontos acima da média. É de referir ainda que essa baixa confiança (no governo e nos políticos) se estende também à confiança social (interpessoal e no altruísmo dos outros) e institucional (Parlamento nacional). Conforme se refere num estudo comparativo de âmbito europeu, os países escandinavos (Dinamarca, Finlândia, Noruega, Suécia) e a Suiça, revelam os mais elevados níveis de confiança nesses dois planos, enquanto que Portugal, Espanha e os países de Leste da Europa (em especial a Polónia, a Hungria e a Eslovénia) revelam resultados opostos, mostrando níveis de confiança muito baixos (CORREIA SILVA, 2011, p. 51-57).

Para concluir este tópico, vale a pena uma referência às representações dos portugueses quanto a dois setores fundamentais: a saúde e a educação. De acordo com as mesmas bases de dados, a apreciação subjetiva dos portugueses no campo da saúde aponta para uma avaliação, em média, negativa ao longo da década, embora com tendência para uma crescente moderação, ou seja, se em 2002 as respostas entre 0 e 4 (na mesma escala de 0 a 10) somavam 70,1\%, nos inquéritos de 2004 e 2006 revelaram um decréscimo para 66,1\%, e 65,3\% respetivamente, baixando ainda de forma mais vincada nos dados de 2008 para 51,9\% de avaliação negativa dos serviços de saúde. Já no caso da educação, as respostas obtidas também ilustram uma perceção pouco satisfatória, evoluindo as respostas - usando o mesmo critério - de $62,3 \%$ de opiniões negativas em 2002, para 59,1\% em 2004, 53,6\% em 2006 e 57,2\% em 2008, revelando neste caso um agravamento no último período (VALA et al., 2010). Sendo as atitudes negativas mais vincadas do que nos restantes países, isso quer dizer que, pelo menos do ponto de vista subjetivo, estes serviços não conseguiram responder às expectativas dos cidadãos, pelo que, apesar de denotarem um ligeiro abrandamento, se revelaram fatores de preocupação e stress psicológico.

Procurando medir a felicidade dos cidadãos a partir de modelos da psicologia social (EASTERLIN, 2001, 2005; VEERNHOVEN; HAGERTY, 2006; VEERNHOVEN, 2011), um estudo recente conduzido por Rui Brites da Silva mostrou que, em termos do indice de bem-estar subjetivo, os portugueses 
ocupam uma posição sofrivel na segunda metade da tabela. No ranking de Veernhoven para o período 2000-2009, Portugal ocupa a $79^{a}$ posição (com 5,7 pontos na escala de 0 a 10) entre 149 países, empatado com a Bielorrússia, Djibuti, Egipto, Mongólia, Nigéria e Roménia. Os primeiros lugares são ocupados pela Costa Rica $\left(1^{\circ}\right.$, com 8,5 pontos na mesma escala), Dinamarca $\left(2^{\circ}\right)$, Islândia $\left(3^{\circ}\right)$, Canadá $\left(4^{\circ}\right)$, Finlândia $\left(5^{\circ}\right)$. Em adição a isto, o aquele estudo, que se apoiou não só nestes indicadores, mas também no relatório da "Comissão Stiglitz", apresenta resultados do índice de bem-estar subjetivo, tentando conjugar as dimensões subjetiva e objetiva da felicidade. Apesar das suas limitações, os critérios utilizados revelaram uma significativa consistência com a avaliação subjetiva dos inquiridos, espelhada nos dados do ESS acima referidos. Além disso, permitiu concluir que o bem-estar subjetivo dos portugueses diminui de Norte para Sul do país, que os índices de felicidade são maiores nos homens do que nas mulheres, e ainda que, os mais baixos índices de bem-estar subjetivo se encontram entre as camadas etárias mais velhas, em particular as do sexo feminino (SILVA, 2011, p. 200-205).

Estas indicações, nomeadamente no que respeita à condição feminina, têm sido assinaladas em vários outros estudos, e são de certo modo coerentes com os dados estatísticos reveladores de que as mulheres trabalham mais em atividades não-remuneradas, trabalham mais horas no espaço doméstico e também continuam a ser vítimas de discriminação salarial e de segregação noutros domínios da vida social (CARMO, 2010; FERREIRA, 2010) como adiante será mencionado. Por outro lado, o fato dos segmentos mais jovens evidenciarem resultados menos negativos no plano das subjetividades deverá prender-se com outras variáveis associadas ao critério geracional que não

5 Esta comissão foi constituída, além de Joseph Stiglitz, por Amartya Sen e J-P. Fitoussi e outros acadêmicos e especialistas, um grupo promovido pelo presidente francês Nicolas Sarkozy. A equipe sugeriu no seu primeiro relatório iniciativas e critérios novos para avaliar o desempenho econômico, tais como: "usar outros indicadores além do PIB nas contas nacionais; verificar o desempenho de setores básicos como saúde e educação; considerar atividades domésticas e levar em conta o padrão de vida das pessoas; acrescentar informações sobre distribuição de riqueza e rendimento; incluir atividades fora do mercado. Uma inovação proposta pelo relatório é a avaliação líquida e não bruta das atividades econômicas, de modo que as extrações de recursos naturais, os impactos ambientais gerados pela produção ou a utilização de stocks sejam levadas em conta". In: site "Planeta Sustentável", acesso em 7/09/2011: http://planetasustentavel.abril.com.br/noticia/desenvolvimento/comissao-stiglitz-senfitoussi-pib-489751.shtml. 
aquelas que dependem diretamente da situação sociolaboral da juventude. $\mathrm{O}$ mundo do trabalho é, portanto, um dos temas que merece atenção, tanto por aquilo que representa do ponto de vista sociológico como pela sua implicação com a questão do Estado social.

\section{Reforma do Estado, precariedade e desigualdades sociais}

Tem sido repetidamente sublinhado que o setor onde as grandes mudanças do neoliberalismo global têm tido um alcance mais evidente e preocupante é o campo laboral. Por isso mesmo, diversas abordagens têm tentado destacar a importância da centralidade do trabalho e com isso procurando mostrar como a esfera econômica não pode continuar a ser pensada separadamente da esfera social (SANTOS, 2003; SILVA, 2007; FERREIRA, 2009; BOAVIDA; NAUMANN, 2007; OLIVEIRA; CARVALHO, 2010; ESTANQUE; COSTA 2011). A atual tendência de precarização das relações de trabalho, de dissociação entre condições profissionais e vínculos laborais, está de fato a pôr em causa os velhos critérios e formas de diálogo, os valores de solidariedade e no fundo o modelo de contrato social inspirado pela filosofia iluminista e consolidado desde o pós-guerra. Não é demais sublinhar que nos últimos vinte anos as transformações ocorridas do mercado de trabalho fustigaram de forma dramática os direitos e a qualidade do emprego. O modelo produtivo que até aos anos oitenta do século passado pôde sustentar uma classe média que parecia em expansão sofreu, entretanto, convulsões profundas que abalaram abruptamente as suas expectativas mais risonhas. $\mathrm{O}$ aumento e a diversificação da precariedade laboral passaram a constituir um dos principais traços de recomposição do mercado de trabalho tanto em Portugal como nos outros países da União Europeia. Vimos assistindo a uma "tendência que traduz o estilhaçar da homogeneização e estabilidade em que assentava o padrão modal do emprego, quanto à natureza do vínculo laboral, ao tempo de trabalho e ao estatuto social do trabalhador" (GONÇALVES, 2010, p. 184). 
Portugal e o Estado Providência | Elísio Estanque

$\mathrm{Na}$ última década, os postos de trabalho em regime de contratos permanentes diminuíram ao mesmo ritmo em que aumentaram os contratos a termo certo. Aliás, o crescimento das situações precárias - ou o que outrora se designava como situações "atípicas" no campo do emprego - têm evoluído para uma profunda alteração do velho padrão de estabilidade, obedecendo hoje a uma multiplicação de situações e de percursos profissionais, bem como no plano subjetivo e das vivências, quer do emprego quer do desemprego, numa reconfiguração permanente, que justifica novos questionamentos sobre essas novas formas de prestação de trabalho que podem designar-se de novas “patologias da democracia laboral” (FERREIRA, 2009, p. 76). Os valores do emprego precário (se somarmos os contratos a termo, os recibos verdes, os trabalhadores temporários e o trabalho a tempo parcial) aproximam-se já dos 28 a 30\% do emprego. Este tipo de contratos aumentou progressivamente e em todas as faixas etárias, sendo a atual geração a que mais sofre com isso, o que acontece, de resto, em muitos países europeus como, por exemplo, a Espanha, a Alemanha, a Suécia e a França onde, tal como em Portugal, mais de 50\% dos trabalhadores desta geração já se encontram em situação precária (Gonçalves, 2010). O desemprego de jovens licenciados tem agravado nos últimos anos, atingido os 55 mil casos (em 2010), embora se saiba - e convém realçá-lo - que os licenciados auferem salários mais elevados e permanecem menos tempo em situação de desemprego ou de trabalho precário. Em todo o caso, quer o desemprego quer os contratos não permanentes atingem especialmente o segmento mais jovem. E isso aconteceu de forma drástica, estando 37,6\% dos trabalhadores com idades entre 15 a 34 em situação laboral de contratos a prazo, e considerando apenas o segmento etário dos 15 aos 24 anos, essa percentagem já se aproximava em 2010 dos 50\% (INE, 2007, Inquérito ao Emprego; CARMO, 2010).

No caso das mulheres, apesar de possuírem um elevado peso no mercado de trabalho português $(56,2 \%$ é a taxa de atividade feminina, uma das mais elevadas da Europa) e da sua presença ser maioritária entre a população empregada que completou o ensino secundário e superior, continuam a ser 
vítimas de segregação no campo profissional, o que se comprova pela sua menor presença nas categorias profissionais mais qualificadas. Considerando as percentagens segundo o sexo por referência ao respetivo peso entre os trabalhadores com niveis de educação mais elevados, verifica-se que enquanto $71,6 \%$ dos homens nessa condição pertencem àquelas categorias (quadros médios e superiores), apenas $54,6 \%$ das mulheres se encontravam em posições idênticas em 2005 (ROSA, 2008). Além disso, as diferenças salariais entre homens e mulheres permanecem acentuadas, sendo que a desigualdade salarial se agrava à medida que consideramos os segmentos profissionais com habilitações escolares mais elevadas.

Os fluxos de mobilidade social ascendente foram reais durante algum tempo, mas oscilaram sempre ao sabor de deslizes e variações em que os ganhos e perdas de meios materiais e status profissionais se anulavam mutuamente. A classe média possui um peso escasso e uma duvidosa solidez, se comparada com as sociedades avançadas da Europa. O sistema de ensino superior, geralmente considerado um dos principais canais de promoção da mobilidade apesar de ter crescido massivamente nas últimas três décadas e acolher hoje um volume significativo de estudantes provenientes dos estratos da classe média-baixa e trabalhadora -, debate-se com indefinições diversas e muitos jovens que o frequentam vêem-se perante a impossibilidade de acederem a uma profissão que lhes garanta um estatuto social substancialmente superior ao das suas famílias de origem.

\section{Estado e desigualdades sociais}

O Estado e o mercado constituem desde sempre instâncias de eleição enquanto fatores de racionalidade dos sistemas sociais, pelo que as políticas de regulação - da economia e da sociedade - se apoiam necessariamente na interligação entre essas duas esferas da vida social. A estruturação da atividade produtiva pode obedecer a uma intervenção direta ou indireta do Estado e ocorre através de uma diversidade de canais, exemplos disso são o investimento em novas tecnologias e em conhecimento científico e a capacidade de promover 
instituições de regulação dos conflitos laborais ou as políticas educativas. Assim, as politicas sociais e laborais coordenadas pelo Estado refletem-se não só na estruturação do mercado de trabalho em geral, mas também, e desde logo, no maior ou menor peso da administração pública na oferta de emprego. Por exemplo, a regulação administrativa nos campos da saúde, da educação, da segurança social, etc., promoveu durante décadas o aumento de setores profissionais qualificados, funcionários administrativos, técnicos e especialistas de diversos tipos.

A acentuada desigualdade na distribuição da riqueza em Portugal tem sido revelada por diversos estudos como um problema estrutural dificil de combater (EUROSTAT, 2006; CARMO, 2010). A diferença entre o rendimento médio dos $20 \%$ mais bem pagos e os $20 \%$ pior remunerados era 7,4 vezes a favor dos primeiros em 1995, tendo desde aí decaído lentamente para 6,8 vezes em 1998, valor que passou a 6,9 no ano 2005, para 6,5 em 2007, e no ano seguinte situou-se em 6,1 (dados do INE, 2008; CARMO, 2010). Note-se ainda que a disparidade das desigualdades de rendimento aumenta se restringirmos os segmentos em comparação: entre os $10 \%$ com salários mais elevados e os $10 \%$ que auferem salários mais baixos a diferença era, em 2006, de cerca de 12 vezes mais. Esta situação, como muitas outras, é bem mais grave em Portugal do que na média dos países da União Europeia (na UE15, o diferencial era no mesmo de 4,8 vezes) e é ainda mais contrastante se a compararmos com um país como a Dinamarca, onde essa discrepância era, no mesmo ano, de apenas de 3,5 vezes.

A relação entre o Estado e a sociedade civil em Portugal sempre foi problemática. Tratando-se embora de uma divisão analitica (e abstrata), ela pode, no entanto, ajudar a clarificar algumas das tensões e ambivalências da atuação do Estado, seja no plano político e institucional, seja no plano das relações com os interesses privados, que por vezes penetram no seu seio e o controlam, não raro condicionando e pervertendo a própria legitimidade democrática. Ou seja, em Portugal "temos um Estado dócil entre os poderes fáticos e forte e arrogante ante as classes populares de quem se espera 
docilidade e obediência" (SANTOS, 2011, p. 109). Mas, por outro lado, também se pode considerar que temos uma sociedade civil organizada (sindicatos, partidos políticos, associações) que é fraca e uma sociedade civil desorganizada (redes primárias, família, relações de vizinhança) que se mostra forte e que, por isso, diversos estudos desenvolvidos no CES a denominaram de "sociedade providência” (HESPANHA; PORTUGAL, 2009; PORTUGAL, 2011).

\section{Considerações finais}

Para concluir, vale a pena formular uma linha de reflexão que exprime uma outra faceta do presente tema, a saber: até que ponto a centralidade que o Estado social continua, hoje, a ocupar no imaginário coletivo dos cidadãos europeus joga um papel fundamental no futuro da Europa?

Uma hipótese explicativa a explorar pode colocar-se nos seguintes termos: o ataque de que tem sido alvo o Estado social europeu constitui um fator decisivo para a instabilidade e conflitualidade que pode generalizar-se na Europa nos próximos tempos. Boa parte das questões que estão na agenda perante a atual crise passa por resolver o dilema entre: uma Europa com mais cidadania, em que o vasto patrimônio construído ao longo do século XX pode continuar a inspirar estratégias de futuro sem deitar por terra os valores da justiça social, da igualdade e da solidariedade, continuando em busca de programas viáveis e eficazes de redistribuição; ou se, em vez disso, insiste num modelo que segue apenas no sentido do aprofundamento do anterior, isto é, que persista no reforço da hegemonia da economia neoliberal e no triunfo irreversivel dos mercados em detrimento da sociedade e do Estado.

Ora, sabendo nós a importância que o Estado social assumiu nas políticas redistributivas e ao mesmo tempo no imaginário dos cidadãos, como se viu atrás, e tendo presente a intensificação das desigualdades estruturais em sociedades onde o princípio liberal e o individualismo são incipientes (na Europa continental pelo menos) é de admitir que a solidez do sistema e a coesão social possam colapsar se o próprio Estado social vier a colapsar. A reforçar esta ideia está o facto de que, ao contrário dos países anglo-saxônicos, 
nas sociedades do Sul da Europa, como Portugal, de forte tradição católica, com laços comunitários e culturas paroquiais muito intensos, e que viveram longas ditaduras de matriz estatal, as novas classes médias (assalariadas) foram estruturadas muito tardiamente. No caso português, sobretudo, foi no período democrático que tal processo teve lugar e muito à sombra do (frágil) Estado-providência, entretanto criado, ou seja, são quase insignificantes os segmentos sociais da classe média (assalariada e mesmo empresarial) que se regem pelos princípios meritocráticos. Foi principalmente a estabilidade e os horizontes de uma carreira segura e previsivel, oferecida em primeira instância pela administração pública (em especial os setores da educação, da saúde e da administração central e local), que serviu de suporte à classe média, pelo que, atingidos tão fortemente como estão a ser na atual situação de austeridade, tais setores venham a inverter muito rapidamente a tendência anterior, enfrentado agora os buracos e vazios nessa rede protetora (o Estado) que até há poucos anos acalentou o sonho da classe média urbana.

No início deste século fazia sentido falar-se de um "efeito classe média" (Estanque, 2003), resultante dessa aura de ilusões que induziu franjas significativas das nossas familias trabalhadoras a julgarem-se como membros da classe média. Mas, hoje, essa fantasia de quem se julgava à beira de um status respeitável e de uma condição econômica desafogada - fortemente estimulada pela aparente facilidade de crédito - esbarra com uma realidade bem mais dura, que nos revela uma "classe média sitiada" (SANTOS, 2011), colocada no limiar de uma inesperada proletarização. Nestas condições é de esperar que a classe média e os seus descendentes, comecem de facto a revoltar-se contra um sistema que a sugou e agora a pretende descartar sem qualquer recompensa (ESTANQUE, 2012).

De certo modo, é isso que exprimem alguns dos atuais movimentos sociolaborais. Ao contrário dos movimentos estudantis e culturais dos anos sessenta e setenta, os mais recentes ciclos e rebeliões sociais, organizados através das redes do ciberespaço e alheios a ideologias politicas, situam-se na fronteira entre um Estado em vias de falência e um mercado de trabalho que se 
limita a prolongar a instabilidade, naturalizando a precariedade e com isso bloqueando as espectativas de milhões de jovens altamente qualificados de alcançarem um emprego digno e seguro. O Estado-providência revelou-se como um balão em vias de esvaziamento: a promessa de uma classe média artificialmente insuflada por um Estado social cuja sustentabilidade a prazo vinha há muito sendo anunciada. Em adição a isto, o agravamento de fenômenos como o terrorismo (com as ameaças e ações violentas do Daesh e outros grupos radicais), a guerra na Síria, a instabilidade geral no Médio oriente e na cintura dos países ex-soviéticos, os problemas no Norte de África, etc., são todo um conjunto de problemas e "prioridades" que tem contribuído para relegar para segundo plano as decisões estruturais que a UE precisa de enfrentar se pretende reafirmar o projeto de uma Europa Federal e Democrática. O "brexit" e as assimetrias entre o Norte e o Sul da Europa são clivagens que tendem a acentuar-se no futuro próximo e a agravar os mais antigos problemas estruturais. Perante todas estas dificuldades, a gravidade da crise econômica tem vindo a mostrar, de forma cada vez mais clara, que as atuais elites europeias (e nacionais) se revelam incapazes de encontrar as respostas adequadas a problemas tão prementes, abrindo agora o campo para a retórica populista da extrema-direita.

Considerando todos estes aspetos, podemos nos perguntar: estarão as instituições europeias em condições de assumir decisões estratégicas capazes de inverter as tendências e ameaças que hoje permanecem? Que papel caberá em particular aos países do Sul europeu para resolver o problema das dívidas soberanas e consolidarem a sua posição na EU? restará à Europa, como último fôlego, uma resposta radical da sua juventude e dos cidadãos em geral que já sofrem intensamente na pele os efeitos da austeridade? Se os movimentos sociais não são em si mesmos (como nunca foram) "a solução", eles constituem um barómetro fundamental que urge interpretar com humildade e inteligência. Quem o fizer - governos, instituições, sindicatos ou partidos políticos - e souber passar à ação poderá estar abrindo caminho às novas lideranças de que a Europa tanto carece. 
Portugal e o Estado Providência | Elísio Estanque

Referências bibliográficas

ANDERSON, Benedict. Imagined Communities: Reflections on the Origin and Spread of Nationalism. Londres: Verso. 1991.

ANTUNES, Ricardo (org.) Riqueza e Miséria do Trabalho no Brasil. São Paulo: Editora Boi Tempo, 2006.

BECK, Ulrich. Un nuevo mundo feliz: la precaridad del trabajo en la era de la globalización. Barcelona: Paidós, 2000.

BOAVIDA, Nuno e NAUMANN, Reinhard (orgs.) O Estado e a Economia: o modelo econômico europeu no século XXI. Lisboa; Fundação Friedrich Ebert, 2007.

BOBBIO, Norberto. O Marxismo e o Estado. Rio de Janeiro: Graal, 1979.

BOEP. Boletim do Observatório do Emprego Público, Dados Estatísticos, $\mathrm{n}^{\circ}$ 04/ Maio, 2011.

BURAWOY, Michael. The Politics of Production. Londres: Verso, 1985.

$\overline{2010 .}$

O Marxismo Encontra Bourdieu. Campinas: Editora da Unicamp,

CARMO, Renato Miguel do (org.) Desigualdades Sociais 2010. Estudos e Indicadores. Lisboa: Observatório das Desigualdades/ Editora Mundos Sociais, 2010.

CARVALHO, Margarida. A persistência das desigualdades remuneratórias de género nas empresas portuguesas: 1988-2008. Observatório das Desigualdades do ISCTE/IUL, 2011. Disponivel em: http://observatorio-dasdesigualdades.cies.iscte.pt/index.jsp?page $=$ projects $\& i d=116$.

CASTEL, Robert. As Metamorfoses da Questão Social. Petrópolis: Editora Vozes, 1998.

CASTELLS, Manuel. A sociedade em Rede - A era da informação: economia, sociedade e cultura, Vol.1, São Paulo: Paz e Terra, 1999.

CLBRL - Comissão do Livro Branco para as Relações Laborais, Lisboa: Ministério do Trabalho e da Solidariedade Social (organizador: António Dornelas). 2007

CRAVINHO, João. A reforma do modelo socioeconômico europeu: deve a Europa reforçar-se para emular o modelo europeu? In: BOAVIDA, Nuno e NAUMANN, Reinhard (orgs.), O Estado e a economia: o modelo econômico europeu no século XXI. Lisboa; Fundação Friedrich Ebert, 2007. 
CRUZ, Manuel Braga da. Europeísmo, nacionalismo, regionalismo. In: Análise Social, vol. XXVII (118-119). Lisboa: ICS, 1992.

EASTERLIN, Richard A. Income and Hapiness: toward a unified theory. The Economic Journal, 111, 2001.

. Feeding the illusion of growth and happiness: A reply to Hagerty and Veenhoven. In: Social Indicators Research, vol. 74, 2005.

ESPING-ANDERSEN, Gøsta. "After de Golden Age? Welfare State Dilemmas in a Global Economy”, In:___. (ed.) Welfare States in Transition: National Adaptations in Global Economies. Londres: Sage, 1996.

ESTANQUE, Elísio. O efeito classe média - desigualdades e oportunidades no limiar do século XXI, In: CABRAL, Manuel Villaverde; VALA, Jorge e FREIRE, André. (orgs.), Percepções e avaliações das desigualdades e da justiça em Portugal numa perspectiva comparada. Lisboa: ICS, 2003.

A Reinvenção do sindicalismo e os novos desafios emancipatórios: do despotismo local à mobilização global, In: SANTOS, Boaventura S. (org.), Trabalhar o Mundo: os caminhos do novo internacionalismo operário. Porto: Afrontamento, 2004.

- A questão social e a democracia no início do século XXI: participação cívica, desigualdades sociais e sindicalismo. Finisterra - Revista de Reflexão Critica, vol. 55/56/57, Lisboa, 2007.

A Classe Média: ascensão e declínio. Lisboa: Fundação Francisco Manuel dos Santos, 2012.

Classe Média e Lutas Sociais. Campinas: Editora da Unicamp, 2015.

ESTANQUE, Elísio e BEBIANO, Rui. Do Activismo à Indiferença: movimentos estudantis em Coimbra. Lisboa: ICS, 2007.

EUROSTAT. Europe in Figures. Eurostat Yearbook 2006-2007. European Comission, 2006.

EVENS, Peter B.; RUESCHEMEYER, Dietrich; SKOCPOL, Theda (eds.) Bringing the State Back in. Cambridge: Cambridge University Press, 1985.

FERREIRA, António Casimiro. Da Sociedade Precária à Sociedade Digna: balanço da evolução social em Portugal 2003-2008. Coimbra: CES, Relatório Preliminar, 2009.

FERREIRA, Virginia (org.) A Igualdade de Mulheres e Homens no Trabalho e no Emprego em Portugal. Lisboa: Comissão para a Igualdade no Trabalho e no Emprego/ Ministério do Trabalho e da Solidariedade Social, 2010. 
FRADE, Catarina. Financial Stress and Over-Indebtedness: A Comparative Study Across Europe. In: NIEMI-KIESILAINEN, Johanna.; RAMSAY, Iain.; e WHITFORD, William. (orgs.), Consumer credit, debt and bankruptcy: Comparative and international perspective. Oxford: Hart Publishing, 2009.

FREIRE, João. Tendências pesadas da evolução do Estado Social em Portugal. Plataforma Barómetro Social, 2011. Acesso em 28 de agosto de 2011. Disponivel em: http:// barometro.com.pt/archives/377.

HESPANHA, Pedro e PORTUGAL, Silvia. Sociedad Providencia. In: A. CATTANI, Antonio; CORAGGIO, José Luis e LAVILLE, Jean-Louis (orgs.), Diccionario de la Otra Economia. Buenos Aires: Universidad Nacional de General Sarmiento, 2009.

JESSOP, Bob. State Theory: Putting the Capitalist State in Its Place. Cambridge: Polity Press, 1990.

Toward a Schumpeterian Workfare State? Preliminary Remarks on Post-Fordist Political economy, Studies in Political Economy, 40, 1993. pp. 7 39.

Laville, Jean-Louis e Roustang, Guy. L'enjeu d'un partenariat entre État et société civile". In: Defourny, Jacques et, al., Economie social au Nord et au Sud. Bruxelles: Deboeck, 1999.

LENINE, Vladimir Ilitch. O Estado e a Revolução. Lisboa: editorial Avante!/ Edições Progresso, 1978 [1917].

LOUÇÃ, Francisco e CALDAS, José M. Castro. Economia(s). Porto: Afrontamento, 2009.

MORRIS, Paul. Community Beyond Tradition, In: HEELAS, Paul et al. (eds.), Detraditionalization. Oxford: Blackwell, 1996.

OLIVEIRA, Luísa e CARVALHO, Helena. Regulação e Mercado de Trabalho: Portugal e a Europa. Lisboa: Edições Sílabo, 2010.

POLANYI, Karl. A Grande Transformação: as origens da nossa época. Rio de Janeiro: Campus, 1980.

PORTUGAL, Sílvia. Dádiva, família e redes sociais, In: PORTUGAL, Sílvia e MARTINS, Paulo Henrique (orgs.), Cidadania, Politicas Públicas e Redes Sociais. Coimbra: Imprensa Universidade Coimbra, 2011.

POUlantZas, Nicos. O Estado, o Poder, o Socialismo. Lisboa: Moraes Editores, 1978. 
RAMOS, Maria da Conceição Pereira, Economia solidária, plural e ética, na promoção do emprego, da cidadania e da coesão social. In: Laboreal, v. VII, n.1, 2011.

ROSA, Eugénio. As Desigualdades em Portugal. Documento de apoio ao XI Congresso da CGTP-IN. Lisboa (mimeo), 2008.

ROSA, Maria João; CHITAS, Paulo. Portugal: os números. Lisboa: Fundação Francisco Manuel dos Santos, 2010.

ROUSSEAU, Jean-Jacques. Do Contrato Social. São Paulo: Ed. Martin Claret, 2000 [1762].

RUIVO, Fernando. O Estado Labirintico: o poder relacional entre poderes local e central em Portugal. Porto: Afrontamento, 2000.

Santos, Boaventura de Sousa, O Estado e a Sociedade em Portugal (19741988). Porto: Afrontamento, 1990.

Pela Mão de Alice: o social e o político na pós-modernidade. Porto: Afrontamento, 1994.

. (org.) Trabalhar o Mundo: os caminhos do internacionalismo operário. Porto: Afrontamento, 2004.

2011.

Portugal: Ensaio contra a autoflagelação. Coimbra: Editora Almedina,

SANTOS, Boaventura de Sousa; AVRITZER, Leonardo. Introdução: para ampliar o cânone democrático. In:

Democratizar a Democracia: os caminhos da democracia participativa. Porto: Afrontamento, 2003.

SANTOS, Boaventura de Sousa; FERREIRA, Sílvia. A reforma do EstadoProvidência entre globalizações conflituantes. In: HESPANHA, Pedro; CARAPINHEIRO, Graça,(orgs.) Risco Social e Incerteza: pode o Estado social recuar mais?. Porto: Afrontamento, 2001.

SILVA, Filipe Carreira da. Metamorfoses do Estado: Portugal e a emergência do Estado neo-social. In: CARMO, Renato Miguel e RODRIGUES, João (orgs.), Onde pára o Estado? Politicas públicas em tempos de crise. Lisboa: Edições Nelson de Matos, 2009. pp. 19-51.

SILVA, Manuel Carvalho da. Trabalho e Sindicalismo em tempo de Globalização. Desenvolvimento. Mafra: Círculo de Leitores, 2007.

SILVA, Rui Brites Correia da. Valores e Felicidade no Século XXI: um retrato sociológico dos portugueses em comparação europeia. Dissertação de Doutoramento. Lisboa: ISCTE-IUL, 2011. 
Portugal e o Estado Providência | Elísio Estanque

SKIDMORE, Paul e BOUND, Kirsten. The Everyday Democracy Index. Londres: DEMOS, 2008.

TILLY, Charles. From Mobilization to Revolution. Addison/Mass: Wesley Publishing Company, 1978.

VALA, Jorge; TORRES, Anália; RAMOS, Alice; e LAVADO, Susana. European Social Survey 2002-2008: Destaques - resultados globais comparativos. Lisboa: ICS/ CIES/FCT, 2010.

VEENHOVEN, Robert. Happiness in Nations. World Database of Happiness. Erasmus University Rotterdam, The Netherlands, 2011. Acesso em 07 de setembro de 2011. Disponivel em: http://worlddatabaseofhappiness.eur.nl/hap_nat/nat_fp.php?mode=1

VEENHOVEN, Ruut; HAGERTY, Michael. Rising happiness in Nations 19462004. A reply to Easterlin, In: Social Indicators Research, v. 79, 2006. Disponivel em: http://publishing.eur.nl/ir/repub/asset/16435/2006a-full.pdf

WRIGHT, Erik Olin, Class, Crisis and the State. Londres: Verso, 1978. 